\title{
Drug resistance and susceptibility testing of Gram negative bacterial isolates from healthy cattle with different $\beta$ - Lactam resistance Phenotypes from Shandong province China
}

\author{
Teste de resistência a drogas e suscetibilidade de isolados bacterianos Gram negativos \\ de bovinos saudáveis com diferentes fenótipos de resistência a $\beta$ - lactâmicos da \\ província de Shandong, China
}

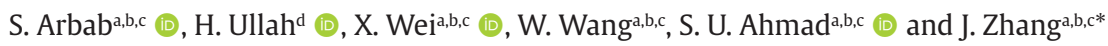 \\ aMinistry of Agriculture, Key Laboratory of Veterinary Pharmaceutical Development, Lanzhou, China \\ 'Lanzhou Institute of Husbandry and Pharmaceutical Sciences, Chinese Academy of Agricultural Sciences, Lanzhou, China \\ 'Key Laboratory of New Animal Drug Project of Gansu Province, Lanzhou, China \\ dSichuan University, West China School of Nursing, West China Hospital, Department of Nursing, Chengdu, China
}

\begin{abstract}
The objective of this study was to evaluate the effectiveness of common antibiotics against different microorganisms in apparently healthy cattle in Shandong province and its suburb. A total of 220 nasal swab samples were collected and cultured for bacteriological evaluation. All the bacteria isolates after preliminary identification were subjected to antibiogram studies following disc diffusion method. It was found in the study that $E$. coli is the most commonly associated isolate (21\%), followed by Klebsiella spp. (18\%), Pseudomonas aeruginosa (13\%), Salmonella spp. (15\%), Shigella spp (12\%), and Proteus spp (11\%). While the antibiogram studies reveled that highest number of bacterial isolates showed resistance to Ampicillin (95\%), followed by Augmentin (91\%), Cefuroxime (85\%) and Tetracycline (95\%) of (Escherichia coli and Klebsiella spp). In the case of pseudomonas spp. and Salmonella the highest resistance was showed by Ampicillin (90\%) followed by Amoxicillin + Clavulanic Acid (80\%), Cefixime (90\%), and Erythromycin (80\%). In Shigella spp and Salmonella spp highest resistance was showed by Amoxicillin, Ceftazidime, Augmentin (60\%), and Amoxicillin + Clavulanic Acid (50\%). It is concluded that in vitro antibiogram studies of bacterial isolates revealed higher resistance for Ampicillin, Augmentin, Cefuroxime, Cefixime, Tetracycline, Erythromycin, and Amoxicillin + Clavulanic Acid. The high multiple Antibiotics resistance indexes (MARI) observed in all the isolates in this study ranging from 0.6 to 0.9 . MARI value of $>0.2$ is suggests multiple antibiotic resistant bacteria and indicate presence of highly resistant bacteria.
\end{abstract}

Keywords: multidrug resistance, healthy animals, infectious agents, antibiotic.

\begin{abstract}
Resumo
O objetivo deste estudo foi avaliar a eficácia dos antibióticos comuns contra diferentes microrganismos em bovinos aparentemente saudáveis na província de Shandong e seus subúrbios. Um total de 220 amostras de esfregaço nasal foi coletado e cultivado para avaliação bacteriológica. Todos os isolados de bactérias após identificação preliminar foram submetidos a estudos de antibiograma seguindo o método de difusão em disco. Verificou-se no estudo que E. coli é o isolado mais comumente associado (21\%), seguido por Klebsiella spp. (18\%), Pseudomonas aeruginosa (13\%), Salmonella spp. (15\%), Shigella spp (12\%) e Proteus spp (11\%). Enquanto os estudos de antibiograma revelaram que o maior número de isolados bacterianos apresentou resistência à Ampicilina (95\%), seguido por Augmentin (91\%), Cefuroxima (85\%) e Tetraciclina (95\%) de (Escherichia coli e Klebsiella spp). No caso de Pseudomonas spp. e Salmonella, a maior resistência foi apresentada pela Ampicilina (90\%) seguida pela Amoxicilina + Ácido Clavulânico (80\%), Cefixima (90\%) e Eritromicina (80\%). Em Shigella spp e Salmonella spp, a maior resistência foi demonstrada por Amoxicilina, Ceftazidima, Augmentina (60\%) e Amoxicilina + Ácido Clavulânico (50\%). Conclui-se que estudos de antibiograma in vitro de isolados bacterianos revelaram maior resistência para Ampicilina, Augmentina, Cefuroxima, Cefixima, Tetraciclina, Eritromicina e Amoxicilina + Ácido Clavulânico. Os altos índices de resistência a antibióticos múltiplos (MARI) observados em todos os isolados neste estudo variaram de 0,6 a 0,9. 0 valor MARI de >0,2 sugere várias bactérias resistentes a antibióticos e indica a presença de bactérias altamente resistentes.
\end{abstract}

Palavras-chave: resistência a múltiplas drogas, animais saudáveis, agentes infecciosos, antibióticos.

*e-mail: infzjy@sina.com; drsafiakandhro@gmail.com

Received: December 29, 2020 - Accepted: February 23, 2021 


\section{Introduction}

Production of extended-spectrum $\beta$-lactamases is the most common mechanism of resistance to third-generation cephalosporin's among Enterobacteriaceae family including Klebsiella pneumoniae and Escherichia coli (Pitout and Laupland, 2008). The recent incidence associated to these bacterial isolates, in companion animals and in livestock, has got the concentration for its monitoring studies in livestock (Smet et al., 2010). $\beta$-lactamases producing $E$. coli isolates are now being frequently detected in foodproducing animals, which can become infection sources or reservoirs of these pathogenic bacteria and enhance the spread of these bacteria (Carattoli, 2008).

Antimicrobial agents are used therapeutically in animals and humans for the control of bacterial infections and is also being incorporated into commercial livestock feed at sub therapeutic doses for growth promotion (Berghiche et al., 2018). The uses of antibiotics have significantly reduced mortality associated with infectious diseases in 20th century; but unfortunately, their massive and irregulated uses, in animal farming, has led to the emergence of bacteria multidrug resistance (MDR) (Berghiche, 2019). However, the emergence of resistance has been a global challenge in the application of antibiotics in both humans and animals. Regardless of the source, antibiotics resistance has been on raise and recently, has been projected to be among the major killer that will contribute to death of more than 10 million people annually by 2050 if the threat is not contained (de Kraker et al., 2016).

Large amount of antibiotics are used for non-human purposes, which largely exceed use for man and the applications in animal husbandry is not for therapeutic purposes, rather as growth promoters, feed additives and for prophylaxis (Abat et al., 2017; Akbar et al., 2014). Furthermore, it is estimated that the global consumption of antibiotics is approximated to be around 70 to $80 \%$ and the projected increase of $67 \%$ by year 2030 (Van Boeckel et al., 2015). This could be explained for the quest of large livestock products for profit making in many countries. Although, the use of antibiotics in farming and agriculture is banned in most European countries for prophylaxis, however, the practice of applications of antibiotics in animal husbandry is still common in many countries across the world (Robinson et al., 2016; Woolhouse et al., 2015). The use of antibiotics in animal husbandry results residual of antibiotics in food of animal origins (Galadima et al., 2018). In China, due to the recent boom in agriculture especially livestock breeding, many farmers resort the uses of antibiotics indiscriminately for prophylaxis and as a growth promoter. Furthermore, poor antibiotic stewardship complicated the scenario, hence, this study, aimed to isolate bacteria of public health importance and their resistance profiles in apparently healthy animals.

\section{Material Methods}

\subsection{Ethics statement}

All animal experiments were carried out in accordance with the recommendations in the Guide for the Care and
Use of Laboratory Animals of the Ministry of Science and Technology of the People's Republic of China, and all efforts were made to minimize suffering. This work was supported by grants from the National Natural Science Foundation of China (No: 31872520); China Agriculture Research System (CARS-37).

\subsection{Sample collection}

The samples were collected from apparently healthy animals which showed no symptom of any illness. A total 220 nasal swab samples were collected with the use of sterile swab stick. The swab was then transferred to its care, labeled and taken to the laboratory.

\subsection{Bacterial isolation and identification}

Swabs sample were cultured overnight into nutrient broth at $37^{\circ} \mathrm{C}$ for the determination of microbial growth and then sub-cultured on Blood agar, Chocolate agar, Sorbitol Macconkey Agar, Eosin Methylene Blue Agar, and Salmonella Shigella agar plates incubated at $37^{\circ} \dot{\mathrm{C}}$ for $24 \mathrm{hr}$. Suspected colonies were selected for further analysis of pure culture of gram negative bacteria using standard microbiological techniques of colony identification with the help of Gram staining and biochemical tests following Bergey's manual of determinative bacteriology (Holt et al., 1994).

\subsection{Antibiotic susceptibility test}

Antibiotic susceptibility testing was done for the identified isolates according to Modified Kirby-Baur disc diffusion method using Muller-Hilton agar and the results were interpreted according to Clinical Laboratory Standards Institute (CLSI, 2017) guidelines. Antibiotic discs were placed over the surface of pre inoculated media using dispenser and gently tap each antibiotic disc onto the surface of the agar with a sterile stick, and incubated at $37^{\circ} \mathrm{C}$ for 24 hours. The double-disk synergy test with cefotaxime and amoxicillin-Clavulanic Acid disks was used for the screening of extended-spectrum of ß-lactamases.

\subsection{Antibiotics used in the study}

The Kirby-Bauer disk diffusion susceptibility test was used to determine the sensitivity or resistance of all confirmed isolates to eighteen different antibiotics namely: Ampicillin (AM) $(10 \mu \mathrm{g})$, Amoxicillin (AMX) $(25 \mu \mathrm{g})$, Amoxicillin + Clavulanic Acid (AMC) $(20 / 10 \mu g)$, Augmentin (AUG) $(30 \mu \mathrm{g})$, Cefotaxime (CTX) $(30 \mu \mathrm{g})$, Ceftazidime (CAZ) $(30 \mu \mathrm{g})$, Cefuroxime (CXM) $(30 \mu \mathrm{g})$, Ciprofloxacin (CPX) $(10 \mu \mathrm{g})$, Cefixime (CXM) $(5 \mu \mathrm{g})$, Cefpodoxime (CP) $(10 \mu \mathrm{g})$, Ofloxacin $(5 \mu \mathrm{g})$, Imipenem $(10 \mu \mathrm{g})$, Tetracycline (30 $\mu)$, Gentamicin (GEN) $(10 \mu \mathrm{g})$, Streptomycin (STR) (10 $\mu \mathrm{g})$, Erythromycin (ERY) (10 $\mu \mathrm{g})$, Chloramphenicol (CHL) $(25 \mu \mathrm{g})$, Nitrofurantoin (NIT), and Cotrimoxazole (STX) $(25 \mu \mathrm{g})$.

\subsection{Determination of Multiple Antibiotic Resistance Index (MARI)}

MARI was calculated using the formula, MARI=a/b where "a" is the number of antibiotics resisted and " $b$ " is the total number of antibiotics used in the study. Isolate 
with MARI value of $>0.2$ suggests multiple antibiotic resistant bacteria and indicate presence of highly resistant bacteria (Krumperman, 1983).

\subsection{Statistical analysis}

The graphic representation was performed using Microsoft Office Excel, 2007.

\section{Results}

\subsection{Confirmation of bacterial isolates}

Identification of bacterial Isolates was based on the detailed morphological and biochemical profiling, whereas the Gram staining were done for the confirmation of the Gram-negative bacteria. A of total (220) samples were collected from Shandong province, the positive yield growth 206 (93\%), of Gram negative bacteria. Whereas E. coli was the most frequently recovered (21\%), bacteria followed by Klebsiella spp. (18\%), Pseudomonas aeruginosa (13\%), Salmonella spp. (15\%), Shigella spp. (12\%), and Proteus spp. (11\%) as shown in (Figure 1), and Supplementary Materials (Table 1).

\subsection{Antibiotic susceptibility patterns of the isolates}

The antibiotic susceptibility results were recorded as resistant, intermediate, and sensitive following the guidelines of Clinical Laboratory Standard Institute (CLSI, 2011). The resistance revealed that the isolates (E. coli and Klebsiella spp.) are highly resistance to Ampicillin, Tetracycline, Augmentin, and Cefuroxime, as shown in (Figure 2), and Supplementary Materials (Table 2).

Pseudomonas aeruginosa and Salmonella spp. isolates that were subjected to antimicrobial testing and interpreted as resistant, to Ampicillin, Tetracycline, Cefixime, Erythromycin, and Amoxicillin + Clavulanic Acid as shown in (Figure 3), and supplementary (Table 3).

Shigella spp. and Proteus spp. isolates showed resistance to at least eight antibiotics. All isolates that were resistant to more than two classes were identified as MDR, Amoxicillin + Clavulanic Acid, Ceftazidime, and Erythromycin as shown in (Figure 4), and Supplementary Materials (Table 4). All the 206 Gram negative microorganisms isolate showed resistance to at least seven antibiotics.

\subsection{Determination of Multiple Antibiotic Resistance Index (MARI)}

Multiple Antibiotic Resistance index of isolates that exhibited resistance to three or more antibiotics were generated dividing number of antibiotics resistant the total number of antibiotics tested (Table 5).

\section{Discussion}

Antibiotic resistance has continued to constitute serious problems not only in human but also in animal husbandry, livestock management, and Veterinary (Lawson, 2008). Thus, it is important to assess the resistance profile of

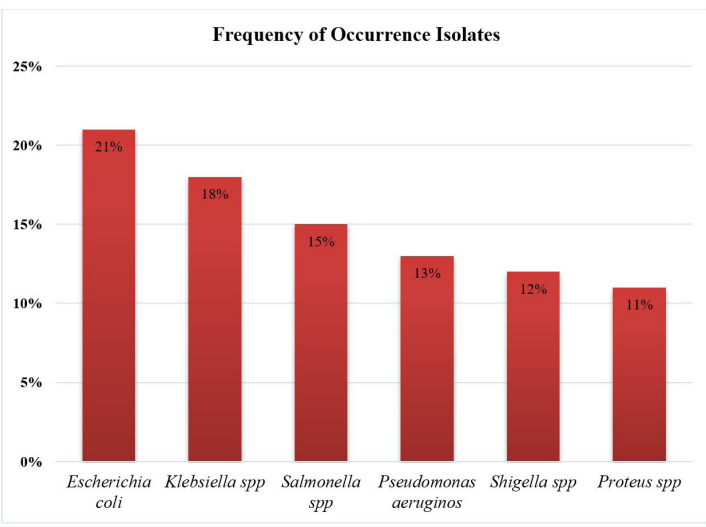

Figure 1. Frequency of occurrence of isolates from different microorganism.

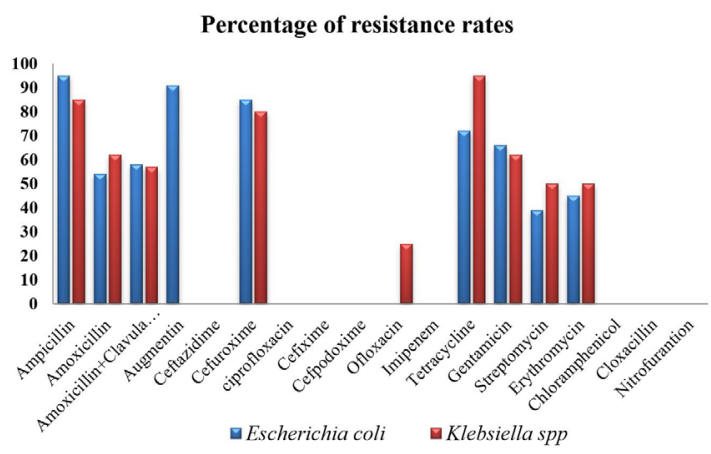

Figure 2. Frequencies of antibiotics resistance in E. coli and Klebsiella spp.

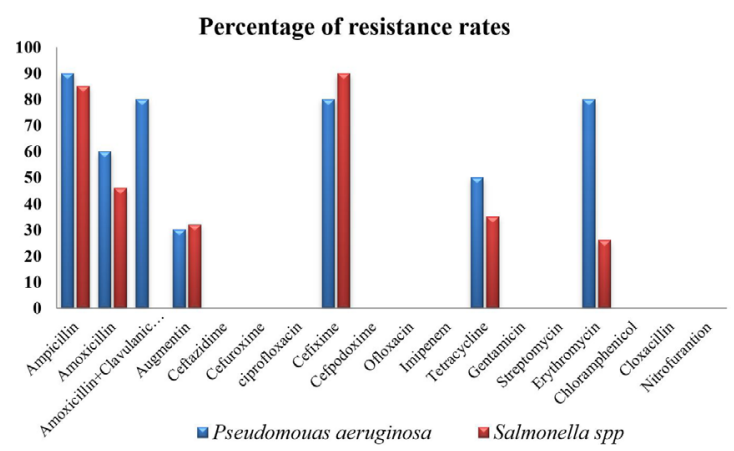

Figure 3. Frequencies of antibiotics resistance in Pseudomonas aeruginosa and salmonella spp.

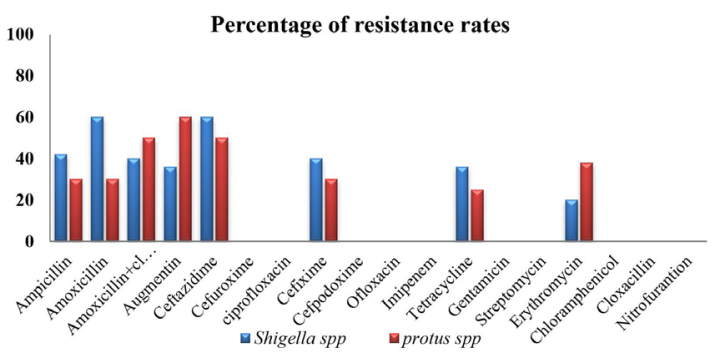

Figure 4. Frequencies of antibiotics resistance in shigella spp and protus spp. 
bacteria among apparently healthy animals as they are common sources of food. We have collected nasal swab samples of cattle to assist the drug resistance profile of isolates from healthy livestock.

The prevalence of bacterial isolates was found 23\%, accounting for large proportion. E. coli and Klebsiella spp. was the most common species isolated in this study, followed by Pseudomonas spp (14.5\%), and Salmonella spp (16.9\%), Shigella spp. (13.59\%) and Proteus spp (12.1\%) respectively. In recent time, it was demonstrated that $E$. coli was predominant species in healthy animals (Oloso et al., 2018), these finding are in agreement with the current study. In a similar manner, high rate of $E$. coli was reported in cows from Jordan (Zhang et al., 2018). These finding are also consistent with other reports where $E$. coli was observed as the predominant species in healthy animals (Oloso et al., 2018).

Overall, the high prevalence of E. coli and occurrence of other bacterial isolates can be explain by being the members of normal flora in animals, however, occurrence of E. coli, Salmonella spp. Pseudomonas spp. Proteus spp. and Klebsiella spp. is a pointer to high burden that have potential risk to animals and human health.

In this study, disk diffusion methods were employed for antibiotic sensitivity testing. The major finding in the present study is the presence of multiple drug resistant E. coli in animals to commonly in use antibiotics such as, Ampicillin (95\%), Augmentin (91\%), Cefotaxime (85\%), Tetracycline (72\%), Gentamicin (66\%), and Amoxicillin + Clavulanic Acid (58\%). This observation reiterates the finding in other studies that have reported antibiotic resistance among bacteria especially $E$. coli isolated from cattle and other animals is increasing at an alarming rate (Ogunleye et al., 2008).

In the present study, MDR Klebsiella spp. was found to be $95 \%$ followed by Tetracycline, Ampicillin (85\%), Cefuroxime (80\%), and amoxicillin+ Clavulanic Acid and Gentamicin (62\%). In a study from China, high rate resistant Klebsiella spp. was reported to be $93.4 \%$ (Cheng et al., 2018). Similar studies documented MDR Klebsiella spp. in cattle (Osman et al., 2014; Tasnim and Islam, 2015). Similar results were reported with high resistance Escherichia coli (35\%), Shigella (33\%) and Salmonella spp. (25\%) (Arbab et al., 2021). MDR isolates in healthy food animals is a serious threat to food safety and public health, as there is well established evidence of resistance transfer through food animals to humans (Chiou et al., 2017).

Isolates originating from this study were shown to be multidrug resistant. The trends in resistance pattern showed that Salmonella spp. Cefixime and Ampicillin (85-90\%) was more resistance than other isolates. This finding shows similar pattern of high resistant Salmonella spp in previous study in China, where the MDR Salmonella spp. reported to be $80 \%$ in food animals when tested against 17 common antibiotics (Lu et al., 2014). Previously, report from Ghana also reported high prevalence of Salmonella spp. (66.7\%) where MDR of the isolates were reported to be $52.8 \%$ (Osei Sekyere and Adu, 2015). Across the world, prevalence of Salmonella spp. were reported in varying degree with very low prevalence in Europe (2\%) than other continents which is in contrast with the current study (Gutema et al., 2019). This variation of occurrence could be accounted for the methods the cattle are handled in different geographical regions.

Resistance pattern showed that Pseudomonas aeruginosa to Ampicillin (90\%), Amoxicillin + Clavulanic Acid (80\%), and Cefixime and Erythromycin (80\%), were intermediate resistant than other isolates. MDR Pseudomonas aeruginosa has been reported with varying degree of resistance to different antibiotics, (93.8\%) to beta-lactam and least resistance to Fluoroquinolone (16\%) (Beier et al., 2015). $P$. aeruginosa as adaptive pathogen, exhibiting multidrug pattern is worrisome. We reported $70 \%$ P. aeruginosa resistance which is in agreement with previous studies depending on the class of antibiotics (Elshafiee et al., 2019). Similar multidrug resistance Pseudomonas aeruginosa has been previously reported in healthy cattle from France and elsewhere (Cheng et al., 2018).

In this study, two other MDR isolates were also reported, Shigella spp and Salmonella spp showed low resistant compared to other isolate Amoxicillin, Ceftazidime and Augmentin (60\%). Researchers reported high levels of resistance for tetracycline. No resistance was observed to Gentamicin, Amikacin, Nalidixic acid, Ofloxacin, Pefloxacin, Cefotaxime, Cefoxitin and Imipinem (Mokhtari et al., 2012). Amongst the food strains, one strain was MDR with resistance to five different antibiotics. There was also a high sensitivity of Shigella spp. strains isolated from the control group to antimicrobial agents (75\%, three of four) (Mokhtari et al., 2012).

The multiple antibiotic resistance index (MARI) of the isolates recovered in the present study indicate multidrug resistance in nature. The MARI value $>0.2$ suggesting multidrug resistance, due to high risk application and contamination of antibiotics (Joseph et al., 2017). These findings demonstrate that the cattle were exposed to multiple antibiotics. On the other hand, a lower MARI index ranging 0.3-0.6 was reported in South African study in food animal (Iwu et al., 2016). Comparable finding also reported lower MARI (0.31) in healthy livestock from South Africa (Nsofor and Iroegbu, 2013). This can be explained by the sample size and antibiotic regulation in the study area, among other factors.

Lack of epidemiological variables, such as history of antibiotic use, to assess the risk factors of exposure and development of resistance and sample size are among the limitation of this study. In addition, molecular analysis could not be performed to determine the resistant gene due to funding constraint. Thus, future studies are required to explore molecular nature of the multidrug resistant genes and the risk factors associated with harboring of drug resistant bacteria in healthy animals in the study area.

\section{Conclusion}

It is concluded that, Escherichia coli and Klebsiella spp. were the most prevalent bacteria in healthy cattle followed by Salmonella spp, Pseudomonas aeruginos, Shigella spp and Proteus spp. The bacterial species, which were 
isolated, are resistant to single of multiple antimicrobial used. The diversity of microorganisms observed in this study support the need of microbial culturing from nasal swab and its antibiotic susceptibility determination for adequate chemotherapy. We also suggest that the routine investigate and monitoring of cattle for bacterial culture and sensitivity studies in various parts of China.

\section{Acknowledgements}

This work was supported by grants from the National Natural Science Foundation of China (No: 31872520); China Agriculture Research System, CARS-37. We also thank Lanzhou Institute of Husbandry and Pharmaceutical Sciences, Chinese Academy of Agricultural Sciences, Lanzhou, China.

\section{Reference}

ABAT, C., ROLAIN, J.-M., DUBOURG, G., FOURNIER, P.-E., CHAUDET, H. and RAOULT, D., 2017. Evaluating the clinical burden and mortality attributable to antibiotic resistance: the disparity of empirical data and simple model estimations. Clinical Infectious Diseases, vol. 65, suppl. 1, pp. S58-S63. http://dx.doi.org/10.1093/ cid/cix346. PMid:28859341.

AKBAR, A., SITARA, U., ALI, I., KHAN, M.I., PHADUNGCHOB, T. and ANAL, A.K., 2014. Presence of Escherichia coli in poultry meat: a potential food safety threat. International Food Research Journal, vol. 21, vol. 3, pp. $941</$ jrn $>-945$.

ARBAB, S., BURIRO, R.S., ULLAH, H., BHUGIO, S.U., SHAH, A.H., KALHORO, D.H., MEMON, M.A., TUNIO, S., VISTRO, W.A. and KHOSO, A.N., 2021. Comparison of antibacterial activity of Ciprofloxacin and Cephalexin against Some common bacterial Species isolates from donkey wounds around the vicinity of Tandojam Sindh Pakistan. Pure and Applied Biology, vol. 10, no. 4, pp. 1095-1103. http://dx.doi.org/10.19045/bspab.2021.100114.

BEIER, R.C., FOLEY, S., DAVIDSON, M., WHITE, D., MCDERMOTT, P., BODEIS-JONES, S., ZHAO, S., ANDREWS, K., CRIPPEN, T., SHEFFIELD, C., POOLE, T.L., ANDERSON, R.C. and NISBET, D.J., 2015. Characterization of antibiotic and disinfectant susceptibility profiles among Pseudomonas aeruginosa veterinary isolates recovered during 1994-2003. Journal of Applied Microbiology, vol. 118, no. 2, pp. 326-342. http://dx.doi.org/10.1111/jam.12707. PMid:25431276.

BERGHICHE, A., 2019. Special attention is needed for reduce antibiotic residue risk in the white meat produced in Algeria. Journal of Food Quality and Hazards Control, vol. 6, pp. 44. http:// dx.doi.org/10.18502/jfqhc.6.2.953.

BERGHICHE, A., KHENENOU, T., KOUZI, A. and LABIAD, I., 2018. An investigation on the predominant diseases, its diagnosis, and commonly used drugs in the poultry farms in the NorthEastern regions of Algeria. Veterinary World, vol. 11, no. 7, pp. 986-989. http://dx.doi.org/10.14202/vetworld.2018.986-989. PMid:30147270.

CARATTOLI, A., 2008. Animal reservoirs for extended spectrum $\beta$-lactamase producers. Clinical Microbiology and Infection, vol. 14, suppl. 1, pp. 117-123. http://dx.doi.org/10.1111/j.14690691.2007.01851.x. PMid:18154535.

CHENG, F., LI, Z., LAN, S., LIU, W., LI, X., ZHOU, Z., SONG, Z., WU, J., ZHANG, M., and SHAN, W., 2018. Characterization of Klebsiella pneumoniae associated with cattle infections in southwest
China using multi-locus sequence typing (MLST), antibiotic resistance and virulence-associated gene profile analysis. Brazilian Journal of Microbiology, vol. 49, supp. 1, pp. 93-100. http://dx.doi.org/10.1016/j.bjm.2018.06.004.

CHIOU, C.-S., CHEN, Y.-T., WANG, Y.-W., LIU, Y.-Y., KUO, H.-C., TU, Y.-H., LIN, A.-C., LIAO, Y.-S. and HONG, Y.-P., 2017. Dissemination of mcr-1-carrying plasmids among colistin-resistant Salmonella strains from humans and food-producing animals in Taiwan. Antimicrobial Agents and Chemotherapy, vol. 61, no. 7, pp. 61. http://dx.doi.org/10.1128/AAC.00338-17. PMid:28416545.

CLINICAL AND LABORATORY STANDARDS INSTITUTE - CLSI, 2011. Clinical and laboratory standards institute. Performance standards for antimicrobial susceptibility testing. Wayne, PA: CLSI.

CLINICAL AND LABORATORY STANDARDS INSTITUTE - CLSI, 2017. M100-S27: Performance Standards for Antimicrobial Susceptibility Testing. 27th ed. Wayne, PA: CLSI. Supplement.

DE KRAKER, M.E., STEWARDSON, A.J. and HARBARTH, S., 2016. Will 10 million people die a year due to antimicrobial resistance by 2050 ? PLoS Medicine, vol. 13, no. 11, pp. e1002184. http:// dx.doi.org/10.1371/journal.pmed.1002184. PMid:27898664.

ELSHAFIEE, E.A., NADER, S.M., DORGHAM, S.M. and HAMZA, D.A., 2019. Carbapenem-resistant Pseudomonas aeruginosa originating from farm animals and people in Egypt. Journal of Veterinary Research, vol. 63, no. 3, pp. 333-337. http://dx.doi.org/10.2478/ jvetres-2019-0049. PMid:31572812.

GALADIMA, H., GEIDAM, Y., SHAMAKI, B., ABDULRAHMAN, H., IBRAHIM, B. and WAZIRI, A., 2018. Survey of antimicrobial residue in table eggs among layer poultry farmers in Maiduguri Metropolis, Borno State. Asian Journal of Animal and Veterinary Advances, vol.13, no. 2, pp. 101-108. http://dx.doi.org/10.3923/ ajava.2018.101.108.

GUTEMA, F.D., AGGA, G.E., ABDI, R.D., DE ZUTTER, L., DUCHATEAU, L. and GABRIËL, S., 2019. Prevalence and serotype diversity of Salmonella in apparently healthy cattle: systematic review and meta-analysis of published studies, 2000-2017. Frontiers in Veterinary Science, vol. 6, pp. 102. http://dx.doi.org/10.3389/ fvets.2019.00102. PMid:31037239.

HOLT, J.G., KRIEG, N.R., SNEATH, P.H., 1994. Bergey's manual of determinative bacterology. Baltimore: Williams \& Wilkins.

IWU, C.J., IWERIEBOR, B.C., OBI, L.C., BASSON, A.K. and OKOH, A.I., 2016. Multidrug-resistant Salmonella isolates from swine in the Eastern cape province, South Africa. Journal of Food Protection, vol. 79, no. 7, pp. 1234-1239. http://dx.doi.org/10.4315/0362028X.JFP-15-224. PMid:27357044.

JOSEPH, A., ODIMAYO, M., OLOKOBA, L., OLOKOBA, A. and POPOOLA, G., 2017. Multiple antibiotic resistance iIndex of EscherichiaColi isolates in a tertiary hospital in south-west Nigeria. Medical Journal of Zambia, vol. 44, pp. 225-232.

KRUMPERMAN, P.H., 1983. Multiple antibiotic resistance indexing of Escherichia coli to identify high-risk sources of fecal contamination of foods. Applied and Environmental Microbiology, vol. 46, no. 1, pp. 165-170. http://dx.doi.org/10.1128/ aem.46.1.165-170.1983. PMid:6351743.

LAWSON, M.A., 2008. The antibiotic resistance problem revisited. The American Biology Teacher, vol. 70, no. 7, pp. 405-410. http:// dx.doi.org/10.1662/0002-7685(2008)70[405:TARPR]2.0.CO;2.

LU, Y., ZHAO, H., SUN, J., LIU, Y., ZHOU, X., BEIER, R.C., WU, G. and HOU, X., 2014. Characterization of multidrug-resistant Salmonella enterica serovars Indiana and Enteritidis from chickens in Eastern China. PLoS One, vol. 9, no. 5, pp. e96050. http://dx.doi. org/10.1371/journal.pone.0096050. PMid:24788434.

MOKHTARI, W., NSAIBIA, S., MAJOURI, D., BEN HASSEN, A., GHARBI, A. and AOUNI, M., 2012. Detection and characterization of 
Shigella species isolated from food and human stool samples in Nabeul, Tunisia, by molecular methods and culture techniques. Journal of Applied Microbiology, vol. 113, no. 1, pp. 209-222. http:// dx.doi.org/10.1111/j.1365-2672.2012.05324.x. PMid:22548495.

NSOFOR, C.A. and IROEGBU, C.U., 2013. Antibiotic resistance profile of Escherichia coli isolated from five major geopolitical zones of Nigeria. African Journal of Bacteriology Research, vol. 5, no. 3 , pp. 29-34. http://dx.doi.org/10.5897/JBR2012.035.

OGUNLEYE, A.O., OYEKUNLE, M.A. and SONIBARE, A.O., 2008. Multidrug resistant Escherichia coli isolates of poultry origin in Abeokuta, South Western Nigeria. Veterinarski Arhiv, vol. 78, pp. 501-509.

OLOSO, N.O., FAGBO, S., GARBATI, M., OLONITOLA, S.O., AWOSANYA, E.J., AWORH, M.K., ADAMU, H., ODETOKUN, I.A. and FASINA, F.O., 2018. Antimicrobial resistance in food animals and the environment in Nigeria: a review. International Journal of Environmental Research and Public Health, vol. 15, no. 6, pp. 1284. http://dx.doi.org/10.3390/ijerph15061284. PMid:29914203.

OSEI SEKYERE, J., ADU, F., 2015. Prevalence of multidrug resistance among Salmonella enterica serovar Typhimurium isolated from pig faeces in Ashanti region, Ghana. International Journal of Antibiotics, vol.2015, pp.1-4. https://doi.org/10.1155/2015/898790.

OSMAN, K.M., HASSAN, H.M., ORABI, A. and ABDELHAFEZ, A.S., 2014. Phenotypic, antimicrobial susceptibility profile and virulence factors of Klebsiella pneumoniae isolated from buffalo and cow mastitic milk. Pathogens and Global Health, vol. 108, no. 4, pp. 191-199. http://dx.doi.org/10.1179/2047773214Y.0000000141. PMid:24915048.

PITOUT, J.D. and LAUPLAND, K.B., 2008. Extended-spectrum $\beta$-lactamase-producing Enterobacteriaceae: an emerging publichealth concern. The Lancet. Infectious Diseases, vol. 8, no. 3, pp. 159-166. http://dx.doi.org/10.1016/S1473-3099(08)70041-0. PMid:18291338.

ROBINSON, T.P., BU, D., CARRIQUE-MAS, J., FÈVRE, E.M., GILBERT, M., GRACE, D., HAY, S.I., JIWAKANON, J., KAKKAR, M., KARIUKI, S., LAXMINARAYAN, R., LUBROTH, J., MAGNUSSON, U., THI NGOC,
P., VAN BOECKEL, T.P. and WOOLHOUSE, M.E., 2016. Antibiotic resistance is the quintessential One Health issue. Transactions of the Royal Society of Tropical Medicine and Hygiene, vol. 110, no. 7, pp. 377-380. http://dx.doi.org/10.1093/trstmh/trw048. PMid:27475987.

SMET, A., VAN NIEUWERBURGH, F., VANDEKERCKHOVE, T.T., MARTEL, A., DEFORCE, D., BUTAYE, P. and HAESEBROUCK, F., 2010. Complete nucleotide sequence of CTX-M-15-plasmids from clinical Escherichia coli isolates: insertional events of transposons and insertion sequences. PLoS One, vol. 5, no. 6, pp. e11202. http://dx.doi.org/10.1371/journal.pone.0011202. PMid:20585456.

TASNIM, U. and ISLAM, M., 2015. Pathogenic and drug resistant bacteria in raw milk of Jessore city: A potential food safety threat. Bangladesh Journal of Veterinary Medicine, vol. 13, no. 1, pp. 71-78. http://dx.doi.org/10.3329/bjvm. v13i1.23723.

VAN BOECKEL, T.P., BROWER, C., GILBERT, M., GRENFELL, B.T., LEVIN, S.A., ROBINSON, T.P., TEILLANT, A. and LAXMINARAYAN, R., 2015. Global trends in antimicrobial use in food animals. Proceedings of the National Academy of Sciences of the United States of America, vol. 112, no. 18, pp. 5649-5654. http://dx.doi. org/10.1073/pnas.1503141112. PMid:25792457.

WOOLHOUSE, M., WARD, M., VAN BUNNIK, B. and FARRAR, J., 2015. Antimicrobial resistance in humans, livestock and the wider environment. Philosophical Transactions of the Royal Society of London. Series B, Biological Sciences, vol. 370, no. 1670, pp. 20140083. http://dx.doi.org/10.1098/rstb.2014.0083. PMid:25918441.

ZHANG, D., ZHANG, Z., HUANG, C., GAO, X., WANG, Z., LIU, Y., TIAN, C., HONG, W., NIU, S. and LIU, M., 2018. The phylogenetic group, antimicrobial susceptibility, and virulence genes of Escherichia coli from clinical bovine mastitis. Journal of Dairy Science, vol. 101, no. 1, pp. 572-580. http://dx.doi.org/10.3168/jds.201713159. PMid:29055550. 


\section{Supplementary Materials}

Supplementary material accompanies this paper.

Table 1. Distribution of gram-negative organisms isolated from cattle.

Table 2. Frequencies of antibiotics resistance of Escherichia coli and Klebsiella spp isolates.

Table 3. Frequencies of antibiotics resistance of Pseudomonas spp and Salmonella spp isolates.

Table 4. Frequencies of antibiotics resistance of Shigella spp and Protus spp isolates.

Table 5. Multiple drug resistance indexes (MARI) of the isolates.

This material is available as part of the online article from http://www.scielo.br/bjb 